\title{
Effect of Myostatin SNP on muscle fiber properties in male Thoroughbred horses during training period
}

\author{
Hirofumi Miyata ${ }^{1}$ Rika Itoh $^{1} \cdot$ Fumio Sato $^{2} \cdot$ Naoya Takebe $^{2}$ - Tetsuro Hada ${ }^{2}$. \\ Teruaki Tozaki ${ }^{3}$
}

Received: 21 July 2017/ Accepted: 5 October 2017/Published online: 20 October 2017

(c) The Physiological Society of Japan and Springer Japan KK 2017

\begin{abstract}
Variants of the Myostatin gene have been shown to have an influence on muscle hypertrophy phenotypes in a wide range of mammalian species. Recently, a Thoroughbred horse with a C-Allele at the g.66493737C/T single-nucleotide polymorphism (SNP) has been reported to be suited to short-distance racing. In this study, we examined the effect of the Myostatin SNP on muscle fiber properties in young Thoroughbred horses during a training period. To investigate the effect of the Myostatin SNP on muscle fiber before training, several mRNA expressions were relatively quantified in biopsy samples from the middle gluteal muscle of 27 untrained male Thoroughbred horses (1.5 years old) using real-time RT-PCR analysis. The remaining muscle samples were used for immunohistochemical analysis to determine the population and area of each fiber type. All measurements were revaluated in biopsy samples of the same horses after a 5-month period of conventional training. Although the expressions of Myostatin mRNA decreased in all SNP genotypes, a
\end{abstract}

All authors contributed equally to this work. HM and RI wrote the main paper, and FS, NT, TH and TT performed experiments extensively. All authors discussed the results and implications and commented on the manuscript at all stages.

Hirofumi Miyata

hiro@yamaguchi-u.ac.jp

1 Biological Sciences, Graduate School of Sciences and Technology for Innovation, Yamaguchi University, Yoshida 1677-1, Yamaguchi 753-8515, Japan

2 Equine Breeding Science, Hidaka Training and Research Center, Japan Racing Association, 535-13, Nishicha, Urakawa, Hokkaido 057-0171, Japan

3 Genetic Analysis Department, Laboratory of Racing Chemistry, 1731-2, Tsurutamachi, Utsunomiya, Tochigi 320-0851, Japan significant decrease was found in only the $\mathrm{C} / \mathrm{C}$ genotype after training. While, expression of VEGFa, PGC1 $\alpha$, and SDHa mRNAs, which relate to the biogenesis of mitochondria and capillaries, was significantly higher (54-82\%) in the $\mathrm{T} / \mathrm{T}$ than the $\mathrm{C} / \mathrm{C}$ genotypes after training. It is suggested that hypertrophy of muscle fiber is directly associated with a decrease in Myostatin mRNA expression in the $\mathrm{C} / \mathrm{C}$ genotype, and that increased expressions of VEGFa, PGC1 $\alpha$, and SDHa in the T/T genotype might be indirectly caused by the Myostatin SNP.

Keywords Myostatin SNP · Horses muscle · Training · Development

\section{Introduction}

Thoroughbreds have been bred mainly with the goal of strengthening running capacity since the early 17 th century [1-3]. As a result, the quantity of skeletal muscles in Thoroughbreds exceeding $50 \%$ of the entire body weight and maximal oxygen intake of nearly $180 \mathrm{ml} \mathrm{O}_{2} / \mathrm{min}$ per body weight have been reported [4]. However, improvement of running capacity by selective mating is considered to have almost reached its limit. With the development of molecular-biological analytical methods, genetic factors determining the running capacity have been attracting attention.

Myostatin has recently been featured as an important molecule controlling the quantity of skeletal muscles. Myostatin is a member of the transforming growth factor $\beta$ family (TGF- $\beta$ ) that inhibits muscle growth by inhibiting proliferation and differentiation of muscle cells, and it is known that suppression of the myostatin expression level induces muscle growth $[5,6]$. It has been reported that 
sequence mutations in the horse myostatin gene are associated with the optimum race distance of Thoroughbreds [7, 8]. According to these reports [7-9], four single-nucleotide polymorphisms (SNPs), g.65809482T $>C$, g.65868604G $>$ T, g.66493737C $>$ T, and g.66539967A $>$ G), have been identified on horse chromosome 18 as candidates for genetic prediction in Thoroughbreds. g.66493737C $>\mathrm{T}$ is located in the 1st intron of the horse myostatin gene and it has been reported to be the most promising candidate gene for optimum race distance. Furthermore, origins and history of this SNP were clearly demonstrated by a combination of population geneticsbased molecular and pedigree approaches in modern and historic horse samples [10].

Activation of satellite cells with proliferative ability is an important factor for hypertrophy of skeletal muscles. Myostatin has been demonstrated to inhibit satellite cell activation in myogenesis after birth [11]. Therefore, there may be a very interesting association between satellite cells and myostatin gene polymorphisms; however, the actual association between myostatin gene polymorphisms and training effects on skeletal muscles has not been determined. In addition to the muscle hypertrophy, it has been reported that muscle oxidative capacity has a great impact on running ability of Thoroughbred horses, especially in the developmental period [12]. Although the importance of training in the early stage of development has been noted in Thoroughbreds [13, 14], most racehorses are trained regularly from about 1.5 years old. Therefore, to consider total running performance of Thoroughbred horses, we evaluated expressions of genes not only for satellite cell-related factors, but also for oxidative metabolism-related factors.

The objective of this study was to clarify the association between the myostatin gene polymorphism (g.66493737, $\mathrm{T} / \mathrm{T}, \mathrm{C} / \mathrm{T}$, and $\mathrm{C} / \mathrm{C}$ genotypes) and the mRNA expression levels of muscle satellite cell-related and oxidative metabolism-related factors in racehorses during the growth period.

\section{Materials and methods}

\section{Animals and training protocol}

All procedures were approved by the Animal Welfare and Ethics Committee of the Japan Racing Association Hidaka Training and Research Center and followed the American Physiological Society's Animal Care Guidelines.

Twenty-seven untrained Thoroughbred horses (male, 1.5 years old) were used in this study. By SNP analysis using PCR methods, 27 horses were identified into three
SNP groups, T/T, T/C, and C/C genotypes $(n=9$ in each group).

The horses were housed individually in $3 \times 3.5-\mathrm{m}$ box stalls. Until October, before starting the exercise, the horses were kept in 1-2-ha pastures for approximately $6 \mathrm{~h} /$ day; and fed concentrate pellets (JRA original 10, NOSAN Co., Kanagawa, Japan) twice a day (approximately $4 \mathrm{~kg} /$ day), and water and Timothy hay were available ad libitum. During the 5-month training period, the horses were fed four times daily with hay (approximately $2 \mathrm{~kg} /$ day), oats (approximately $2 \mathrm{~kg} / \mathrm{day}$ ), and complete industrial feed (approximately $5 \mathrm{~kg} / \mathrm{day}$ ), and water and Timothy hay were available ad libitum.

The exercise regimen was according to a traditional training schedule for young horses: two high-intensity training sessions per week followed by three or four lowintensity sessions. Through the end of January, after warm-up on a walking machine, the horses cantered $1600 \mathrm{~m}$ on a flat-track course at mild speed with the last $500 \mathrm{~m}$ completed at $9.0 \mathrm{~m} / \mathrm{s}$, twice a week, and they galloped $1000 \mathrm{~m}$ on a slope course (peak incline of $5.5^{\circ}$ ) at an average speed of $10 \mathrm{~m} / \mathrm{s}$ twice a week. On the other 2 days, the horses cantered $2400 \mathrm{~m}$ at a speed of between 7.7 and $9.0 \mathrm{~m} / \mathrm{s}$ on a flat course. In February to March, the exercise intensity was gradually increased. The horses warmed up by trotting $800 \mathrm{~m}$, then galloped for 2 rounds of $1000 \mathrm{~m}$ on a slope course at an average speed ranging between 10.0 and $12.5 \mathrm{~m} / \mathrm{s}$, twice a week. On the other the 4 days, the horses cantered $2400 \mathrm{~m}$ at speeds ranging from 7.7 to $9.0 \mathrm{~m} / \mathrm{s}$ on a flat-track course. The horses cooled down by walking approximately $2400 \mathrm{~m}$ every training day. Other than the training sessions, the horses were pastured in small individual paddocks for about $4 \mathrm{~h}$ a day.

\section{Muscle sampling}

Muscle samples ( 20 mg wet weight) were obtained from the same area (concentrically $2 \mathrm{~cm}$ away from the first sampling point) at the mid-section of the gluteus medius muscle and from the same depth $(5 \mathrm{~cm}$ below the skin surface) by $18 \mathrm{G} \times 9$-cm needle biopsy (SuperCore Biopsy Instrument, Argon Medical, Device Japan Inc., Tokyo, Japan), under local anesthesia (Lidocaine, Fujisawa Pharmaceutical Co., Osaka, Japan) before starting exercise training and after a 5-month period of conventional training. In a previous study [14], we confirmed an interval of 14 days after exhaustive exercise is sufficient to recover all mRNA expressions to resting levels. All muscle samples were frozen by liquid nitrogen and stored at $-80{ }^{\circ} \mathrm{C}$ until analyzed. 


\section{Immunohistochemical analysis}

The fiber-type population was determined as previously described [12]. Several serial $7-\mu \mathrm{m}$ cross sections of the muscle were obtained on a cryostat (Leica CM510, Nussloch, Germany) at $-20{ }^{\circ} \mathrm{C}$. The sections were warmed to room temperature (RT) and then pre-incubated in $1 \%$ normal goat serum (Millipore-Chemicon, Billerica, MA, USA) in $0.1 \mathrm{M}$ phosphate buffered saline (PBS, pH 7.6) at RT for $10 \mathrm{~min}$. The primary monoclonal antibody was then applied, either (1) fast myosin (SIGMA, St. Louis, USA; 1:4000), which specifically reacts with myosin heavy chain (MHC)-IIa and -IIx, or (2) SC-71 (Developmental Studies Hybridoma Bank, Iowa, USA; 1:1000), which specifically reacts with MHC-IIa. The sections were incubated in these primary antibodies overnight at RT, and incubated with a secondary antibody (goat anti-mouse $\operatorname{IgG}$ ) conjugated with horseradish peroxidase (HRP, Bio-Rad, Hercules, CA, USA; 1:1000) at RT for $3 \mathrm{~h}$. Diaminobenzidine tetrahydrochloride (Bio-Rad) was used as a chromogen to localize HRP. Images of the stained muscle fibers were recorded with a photomicroscopic (E600, Nikon, Tokyo, Japan) image-processing system (DS-U1, Nikon). The fibers were classified as type I, IIa, or IIx fibers based on their immunohistochemical staining properties, and the population percentage and cross-sectional area (CSA) of each muscle fiber type were calculated from at least 50 muscle fibers.

\section{RNA isolation and real-time RT-PCR}

Total RNA was extracted from each muscle sample with TRIzol reagent (Invitrogen, Carlsbad, CA, USA). cDNA was synthesized using TURBO DNase (Ambion, Austin, TX, USA) and ExscriptTM RT reagent kit (Takara, Tokyo, Japan). Relative quantification of mRNA expressions with real-time RT-PCR system (Applied Biosystems Japan, Tokyo, Japan) was performed, as described previously [15]. The relative expression of the target gene was calculated as the relative quantification value for one horse in the A/A genotype before training, using glyceraldehyde-3phosphate dehydrogenase (GAPDH) mRNA as an internal control.

The sequences of the specific primers used in this study are presented in Table 1. Each PCR primer was designed by Primer Express ${ }^{\circledR}$ software (Applied Biosystems, Japan), and the oligonucleotides were purchased from FASMAC (FASMAC, Kanagawa, Japan).

\section{Statistics}

All data are presented as the mean \pm SEM, and analyzed by two-way ANOVA and $t$ test with Bonferroni adjustment for comparison between before and after training period, and among SNP groups. In all cases, statistical significance was set at $p<0.05$.

\section{Results}

\section{Body weight}

Before the training period, average body weights were $444 \pm 8.4,438 \pm 6.8$, and $470 \pm 6.5 \mathrm{~kg}$ before training, and $467 \pm 7.8,452 \pm 6.2$ and $486 \pm 7.4 \mathrm{~kg}$ after training in $\mathrm{T} / \mathrm{T}, \mathrm{C} / \mathrm{T}$, and $\mathrm{C} / \mathrm{C}$ types, respectively (Table 2). The growth rates of body weight during the training period were 5.0, 3.2, and $3.5 \%$ in $\mathrm{T} / \mathrm{T}, \mathrm{C} / \mathrm{T}$, and $\mathrm{C} / \mathrm{C}$ genotypes, respectively. Significant increases in body weight were found in all genotypes after training. Although the body weight in $\mathrm{C} / \mathrm{C}$ genotype showed a heavier than other two groups, the significant differences were not detected among these genotypes.

\section{Histochemical properties of muscle fiber}

In this study, muscle fiber types were classified in type I, type IIa, and type IIx fibers by immunohistochemical procedure, then muscle fiber population $(\%)$ and area $\left(\mu \mathrm{m}^{2}\right)$ of each fiber type were summarized in Table 2.

Any significant differences in fiber type population were not detected among all the genotypes at both before and after the training period. While, as compared to before training, the population of type IIx fiber showed a tendency to decrease after training in all the genotypes, and a significant decrease was found in T/T genotype.

Any significant differences in fiber type area were not found among the genotypes at both before and after the training period. As compared to before training, the area of type IIx fiber showed a tendency to increase after training in all the genotypes, and a significant increase was found in $\mathrm{C} / \mathrm{C}$ genotype.

\section{mRNA expression}

\section{Molecules related to satellite cell}

Expressions of Myostatin, Pax7, MyoD, Myogenin, and HGF mRNAs are shown in Fig. 1a-e. The expression of Myostatin mRNA decreased in all the genotypes after training, and significant decrease was found in $\mathrm{C} / \mathrm{C}$ genotype. The expression of Pax7, marker of satellite cell, significantly increased after training in all the genotypes. The expressions of MyoD and Myogenin mRNA, proliferation and differentiation makers of satellite cell, significantly increased in only $\mathrm{T} / \mathrm{T}$ genotype after training and 
Table 1 Real-time reverse transcriptional (RT)-PCR primer sequences

\begin{tabular}{lll}
\hline & Forward sequence & Reverse sequence \\
\hline GAPDH & CAAGGCTGTGGGCAAGGT & GGAAGGCCATGCCAGTGA \\
Myostatin & TGACAGCAGTGATGGCTCTT & TTGGGTTTTCCTCCACTTG \\
Pax7 & CATCGGCGGCAGCAA & TCCTCGATCTTTTTCTCCACATC \\
MyoD & ACGGCTCTCTCTGCAACTTTG & GAGTCGAAACACGGGTCATCA \\
myogenin & TCACGGCTGACCCTACAGATG & GGTGATGCTGTCCACAATGG \\
SDHa & AGGTTTGCTGATGGCAGTATAAGA & TGCATCGACTTCTGCATGCT \\
VEGFa & CCCACTGCGGAGTTCAACAT & TTGGCTTTGGTGAGGTTTGAT \\
PGC1 $\alpha$ & TCCGTGTCACCACCCAAAT & TGAACGAGAGCGCATCCTT \\
HGF & GGTACGCTACGAAGTCTGTGACA & CCCATTGCAGGTCATGCAT \\
MHC1 & GGAATGACAACTCCTCTCGCTTT & TCAATATCAGCAGAAGCCAGTTTC \\
MHC2 & CCCATGAACCCTCCCAAATA & GCAGGCTCATGCAGGTGAGT \\
\hline
\end{tabular}

GAPDH glyceraldehydes-3-phosphate dehydrogenase, $\operatorname{Pax} 7$ paired box transcription factor-7, MyoD myogenic determination factor, $S D H a$ succinate dehydrogenase subunit a, $V E G F a$ vascular endothelial growth factor-A, $P G C 1 \alpha$ peroxisome proliferator-activated receptor $\gamma$ coactivator-1 $\alpha, H G F$ hepatocyte growth factor, $M H C$ Myosin heavy chain

Table 2 Body weight and muscle fiber properties (population and area) before and after training of Thoroughbred horses in each genotype (g.66493737C/T: T/T, C/T and C/C genotypes)

\begin{tabular}{|c|c|c|c|c|c|c|}
\hline \multirow[b]{2}{*}{ Body weight (kg) } & \multicolumn{3}{|c|}{ Before training } & \multicolumn{3}{|l|}{ After training } \\
\hline & $\begin{array}{l}\mathrm{T} / \mathrm{T} \\
444 \pm 8.4\end{array}$ & $\begin{array}{l}\mathrm{C} / \mathrm{T} \\
438 \pm 6.8\end{array}$ & $\begin{array}{l}\mathrm{C} / \mathrm{C} \\
470 \pm 6.5\end{array}$ & $\begin{array}{l}\mathrm{T} / \mathrm{T} \\
467 \pm 7.8^{*}\end{array}$ & $\begin{array}{l}\mathrm{C} / \mathrm{T} \\
452 \pm 6.2^{*}\end{array}$ & $\begin{array}{l}\mathrm{C} / \mathrm{C} \\
486 \pm 7.4^{*}\end{array}$ \\
\hline \multicolumn{7}{|l|}{ Population (\%) } \\
\hline Type I & $11.1 \pm 1.9$ & $13.7 \pm 2.8$ & $7.5 \pm 1.9$ & $15.7 \pm 11.1$ & $13.8 \pm 9.1$ & $9.4 \pm 6.5$ \\
\hline Type IIa & $40.4 \pm 4.5$ & $41.5 \pm 3.5$ & $40.8 \pm 2.6$ & $48.7 \pm 5.9$ & $45.8 \pm 6.4$ & $45.5 \pm 7.8$ \\
\hline Type IIx & $48.5 \pm 5.2$ & 44. $8 \pm 2.6$ & $51.7 \pm 2.5$ & $35.6 \pm 12.7 *$ & $40.4 \pm 10.7$ & $45.1 \pm 9.4$ \\
\hline \multicolumn{7}{|l|}{ Area $\left(\mu \mathrm{m}^{2}\right)$} \\
\hline Type I & $2230 \pm 186$ & $1749 \pm 64$ & $2487 \pm 300$ & $2577 \pm 291$ & $2445 \pm 299$ & $2626 \pm 284$ \\
\hline Type IIa & $2543 \pm 179$ & $2522 \pm 174$ & $2202 \pm 158$ & $2753 \pm 129$ & $2838 \pm 218$ & $2816 \pm 331$ \\
\hline Type IIx & $3939 \pm 299$ & $3538 \pm 298$ & $3832 \pm 332$ & $4233 \pm 450$ & $3898 \pm 378$ & $4647 \pm 325 *$ \\
\hline
\end{tabular}

Values are mean $\pm \operatorname{SEM}(n=9$ in each group $)$

* Significant difference $(P<0.05)$ between before and after training in same genotype group

significant difference of Myogenin mRNA was found between $\mathrm{T} / \mathrm{T}$ and $\mathrm{C} / \mathrm{T}$ genotypes after training. The expression of HGF mRNA, activator of satellite cell, showed a tendency to increase in all the genotypes, and significant increase was found in only $\mathrm{C} / \mathrm{T}$ genotype.

\section{Molecules related to oxidative metabolism}

Expressions of SDHa, PGC1 $\alpha$, and VEGFa mRNA are shown in Fig. 2a-c, respectively. The expression of SDHa mRNA, maker of mitochondria, significantly increased after training in all the genotypes, and the value was significantly higher in $\mathrm{T} / \mathrm{T}$ than $\mathrm{C} / \mathrm{C}$ genotypes after training. The expression of PGC1 $\alpha$ mRNA increased in all the genotypes after training, and significant increase was found in only $\mathrm{C} / \mathrm{C}$ genotype. The expression of VEGFa mRNA, maker of angiogenesis, unchanged after training in all the genotypes, and the value was significantly higher in $\mathrm{T} / \mathrm{T}$ than $\mathrm{C} / \mathrm{C}$ genotypes after training.

\section{Myosin heavy chain (MHC)}

Expressions of MHC I and II mRNA are shown in Fig. 3a, $\mathrm{b}$, respectively. No significant differences were found in either MHC expression among all the genotypes. The expression of MHC I significantly decreased in $\mathrm{C} / \mathrm{C}$ after training. On the other hand, the expression of MHC II significantly increased in T/T genotype after training. 
(a) Myostatin

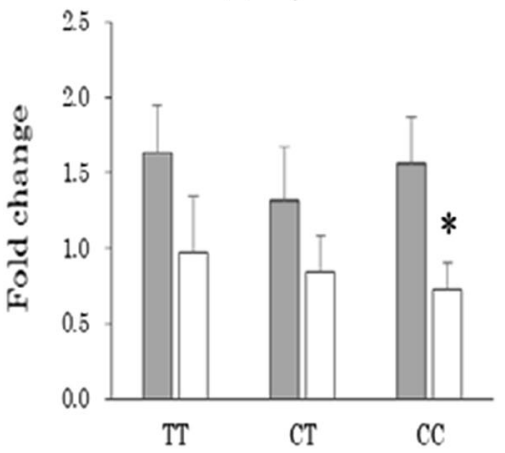

(d) Myogenin

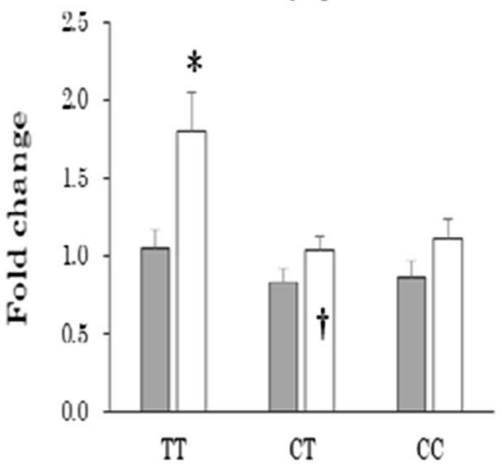

(b) PAX7

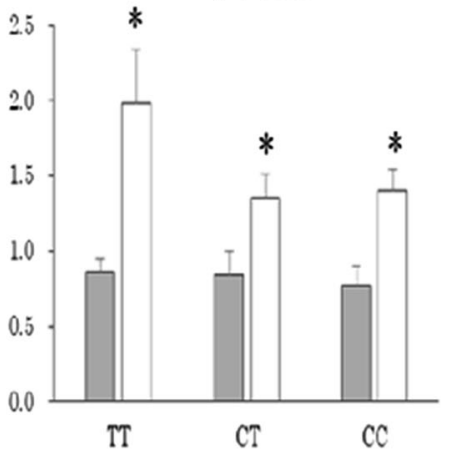

(e) HGF

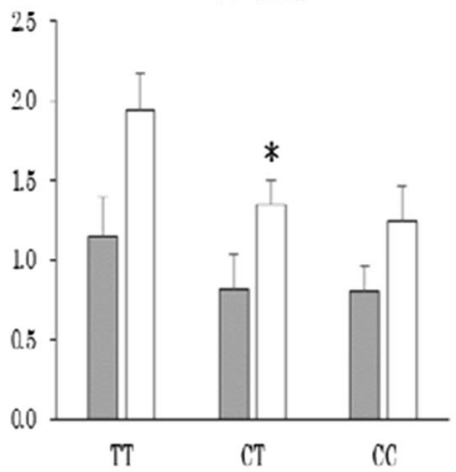

(c) $\mathrm{MyoD}$

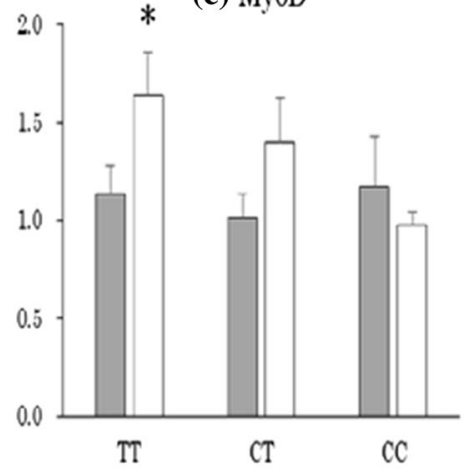

Fig. 1 Comparison of relative expressions of mRNA in Myostatin (a), MyoD (b), Myogenin (d), and HGF (e) in Thoroughbred horses' muscles in each genotype before (gray bar) and after (white bar) training period. Data of one horse in T/T genotype was set at base line value (1) in each mRNA. Values are mean \pm SEM $(n=9$ in each group). *Significant difference $(P<0.05)$ between before and after training in same SNP group. 'Significant difference $(P<0.05)$ as compared to each value in $\mathrm{T} / \mathrm{T}$ genotype (a) $\mathrm{SDHa}$

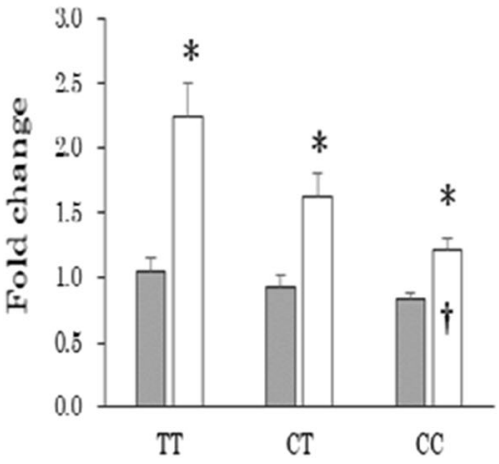

(b) $\mathrm{PGCl}$

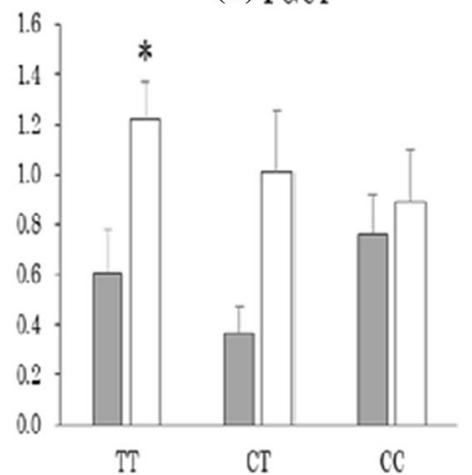

(c) VEGita

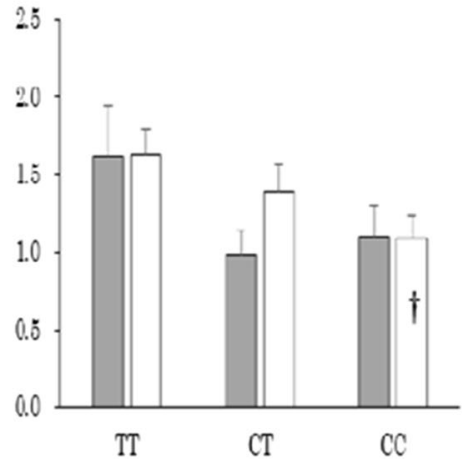

Fig. 2 Comparison of relative expressions of mRNA in SDHa (a), PGC-1 $\alpha(\mathbf{b})$, and VEGFa (c) in Thoroughbred horses' muscles in each genotype before (gray bar) and after (white bar) training period. Data of one horse in T/T genotype was set at base line value (1) in each

\section{Discussion}

This study was performed to examine whether training effects are influenced by the myostatin SNP in racehorses during the growth period. On histochemical analysis, no difference due to the myostatin SNP was noted in the
mRNA. Values are mean $\pm \operatorname{SEM}(n=9$ in each group). $*$ Significant difference $(P<0.05)$ between before and after training in same SNP group. ${ }^{\dagger}$ Significant difference $(P<0.05)$ as compared to each value in $\mathrm{T} / \mathrm{T}$ genotype

muscle fiber population or area before training, but the type IIx fiber population in T/T genotype was significantly decreased by training. In addition, training significantly decreased the $\mathrm{C} / \mathrm{C}$ genotype myostatin mRNA expression level and type IIx fibers significantly hypertrophied. Furthermore, the most marked difference among all the 
Fig. 3 Comparison of relative expressions of mRNA in SDHa (a), PGC- $1 \alpha$ (b), and VEGF-A (c) in Thoroughbred horses' muscles in each genotype group before (gray bar) and after (white bar) training period. Data of one horse in T/T genotype was set at base line value (1) in each mRNA. Values are mean $\pm \operatorname{SEM}(n=9$ in each group). *Significant difference $(P<0.05)$ between before and after training in same SNP group

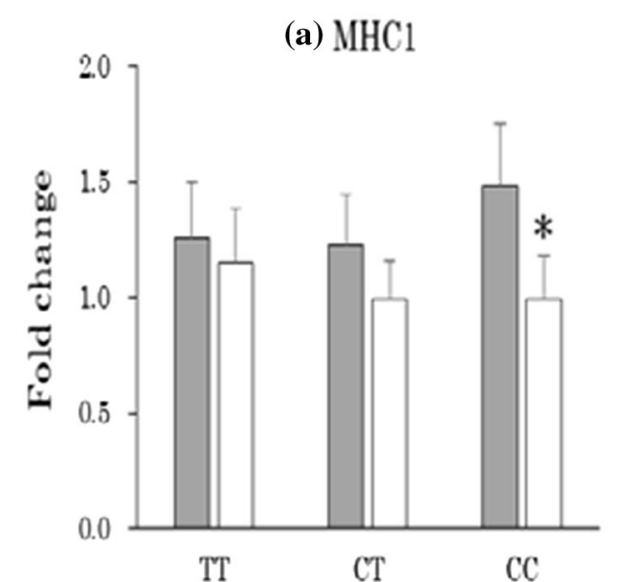

(b) MHC2

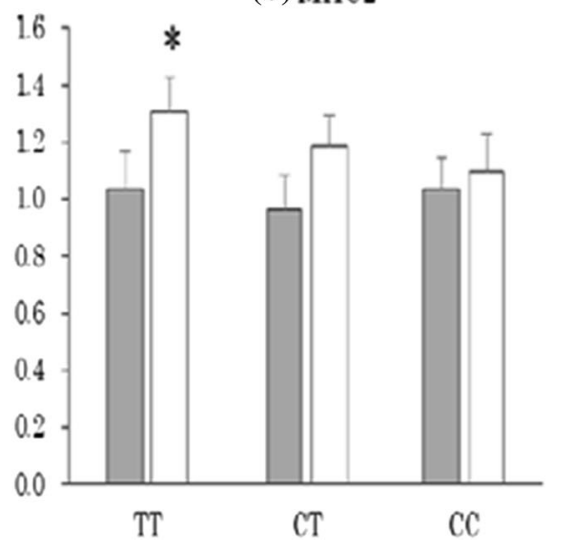

genotypes was a marked increase in the mRNA expression level of molecules (SDHa and PGC1 $\alpha$ ) involved in mitochondrial biogenesis in the $\mathrm{T} / \mathrm{T}$ type after training.

\section{Myostatin SNP and muscle growth}

Myostatin gene mutations are highly conserved among mammals, such as cattle [16, 17], dogs [18], mice [19], sheep [20], and humans [21], and are associated with the phenotype of muscular hypertrophy. This is attractive, particularly in Thoroughbreds, because myostatin mutations influence the lifetime earnings, lifetime rank, and optimum race distance $[8,22]$.

Muscle fibers were classified into types I, IIa, and IIx using immunohistochemical staining [12], and their associations with the SNP (g.66493737C > T) were investigated. Type I fibers contract slowly with high endurance, having a high oxygen supply capacity. Type IIx fibers contract fast and appropriate for exerting power. The characteristics of type IIa fibers are intermediate between these. Accordingly, it was expected based on the findings in preceding studies [23] that the population of type IIx fibers is high in the $\mathrm{C} / \mathrm{C}$ genotype or these fibers hypertrophied, but no difference due to the myostatin SNP was noted in the histochemical characteristics before training. On analysis of the mRNA expression level, no significant difference was noted in the expression level of any molecule, including myostatin, among the SNP groups. These findings suggested that the myostatin SNP did not cause any difference at the muscle fiber level throughout the 1.5-year period after birth, consistent with the findings of previous reports.

Many previous studies demonstrated that although the population of type I fibers did not change, the population of type IIA and IIX fibers significantly increased and decreased with conventional training, respectively $[12,24]$. In this study, although the body weight gain was comparable among the three genotypes after training, when the area was investigated by the muscle fiber type, a significant increase was noted only in the C/C type IIx fibers. This indicates that the training effects on glycolysis-dominant muscle fibers were high in the $\mathrm{C} / \mathrm{C}$ genotypes, suggesting that $\mathrm{C} / \mathrm{C}$ genotype horses grow into racehorses with an aptitude for short distance [7, 22]. A decrease in the myostatin mRNA expression level is generally observed after training $[25,26]$ as a cause of this histological change. The finding that the myostatin mRNA expression level significantly decreased only in the $\mathrm{C} / \mathrm{C}$ genotypes is consistent with hypertrophy of type IIx fibers in the C/C genotypes. Selective IIx fiber hypertrophy is interpreted as a factor for why the $\mathrm{C} / \mathrm{C}$ genotypes rapidly reach the maximum speed and why the speed is higher compared with that of the T/T genotypes [27]. Although it is difficult to explain how the myostatin SNP is associated with expression of the muscle fiber phenotype, we speculate that the SNP in the first intron of the myostatin gene may be a connection site of enhancer factors, as shown in previous studies [28, 29].

Satellite cell activation plays an important role in muscular hypertrophy. We investigated the satellite cell activator HGF [30], Pax7 expression in resting satellite cells, which is required for satellite cell pool formation in skeletal muscles [31], and the proliferation/differentiation markers of satellite cells MyoD and Myogenin [32-34]. Unexpectedly, satellite cell activator and proliferation/differentiation-related factors were significantly increased in the $\mathrm{T} / \mathrm{T}$ genotype than in the $\mathrm{C} / \mathrm{C}$ genotype. It has recently been reported that satellite cells secrete soluble capillary blood vessel growth factor, which is associated with capillary angiogenesis $[35,36]$. Indeed, the VEGF expression level was significantly elevated in the T/T genotype compared with that in the $\mathrm{C} / \mathrm{C}$ genotype, suggesting that $\mathrm{T} / \mathrm{T}$ genotype satellite cell activity contributed to capillary angiogenesis, but not to muscular hypertrophy. 


\section{Myostatin SNP and oxidative metabolic capacity}

On analysis of the mRNA expression levels before training, no significant difference was noted in the mRNA expression levels of SDHa, PGC- $1 \alpha$, or VEGFa related to mitochondria and vascularization among the SNP groups. In contrast, on analysis after training, all these expression levels increased from those before training, and the increases in SDHa and PGC- $1 \alpha$ mRNA were significant in the $\mathrm{T} / \mathrm{T}$ genotype, resulting in significantly higher mRNA expression levels of SDHa and VEGFa in the T/T genotype than in the $\mathrm{C} / \mathrm{C}$ genotype. These findings suggested that vascularization was more strongly promoted in the $\mathrm{T} / \mathrm{T}$ genotype, increasing oxygen supply capacity and promoting mitochondrial biogenesis in cells, thereby increasing ATP production. In addition, this may have led to the histochemical characteristic that the type I fiber area was greater in the T/T genotype.

The expression levels of all oxidative metabolism-related factors after training were the highest in the $\mathrm{T} / \mathrm{T}$ genotype followed by the $\mathrm{C} / \mathrm{T}$ genotype, and lowest in the $\mathrm{C} / \mathrm{C}$ genotype. This order is consistent with the histochemical analysis in which the population of the type I fibers with superior oxygen supply capacity was high in the $\mathrm{T} / \mathrm{T}$ genotype. In addition, increases in SDHa related with the quantity of mitochondria and PGC- $1 \alpha$-promoted mitochondrial biogenesis by training were confirmed in all the genotypes. The high oxygen supply and utilization capacity of the $\mathrm{T} / \mathrm{T}$ genotype may have been due to the strong promotion of vascularization and mitochondrial biogenesis. In addition, based on histochemical analysis, the type I fiber population was increased by training and the fibers became muscles appropriate for endurance exercise in all the genotypes, which suggests that the training performed was effective to improve endurance in all the genotypes. These findings may explain why the $\mathrm{C} / \mathrm{C}$ genotype was very rare in Egyptian Arabian horses with excellent endurance [7].

In previous studies [5, 37], although nearly total ablation of myostatin signaling caused by specific signaling blockade elicits a decrease in oxidative metabolism, a modest decrease of myostatin signaling enhances oxidative metabolism [6]. These results also support a complicated role of myostatin in the regulation of energy metabolism, either directly or indirectly. Our study also could not clarify how the myostatin SNP is associated with expression of the oxidative metabolism-related factor genes. In previous study [21], the presence of a point mutation in the first intron of the myostatin gene region and subsequent myostatin translocation due to abnormal splicing have been identified in a human with marked muscular hypertrophy from immediately after birth. As the myostatin SNP in Thoroughbreds is also present in the first intron, a similar mechanism that not only influences muscular hypertrophy but also directly or indirectly affects gene expression of oxidative metabolism-related factors may be present. Therefore, multifaceted investigation of the mechanism of myostatin SNP with regard to the influences on expression of other genes and actual muscular function is awaited.

Acknowledgements We are grateful to all staff of the JRA Hidaka Training and Research Center for collaboration in sample collection. The monoclonal antibody SC 71 developed by Dr. Schiaffino was obtained from the Developmental Studies Hybridoma Bank developed under the auspices of the NICHD and maintained by the University of Iowa, Department of Biology, Iowa City, USA. This work was supported in part by a grant from The Japanese Ministry of Education, Science and Culture (No. 16H03221).

\section{Compliance with ethical standards}

Conflict of interest The authors declare that they have no conflicts of interest.

Ethical approval All applicable international, national, and/or institutional guidelines for the care and use of animals were followed. All procedures performed in studies involving animals were in accordance with the ethical standards of the institution or practice at which the studies were conducted.

\section{References}

1. Bower M, Campana M, Whitten C, Edwards C, Jones H, Barrett E, Cassidy R, Nisbet RE, Hill EW, Howe C, Binns M (2011) The cosmopolitan maternal heritage of the Thoroughbred racehorse breed shows a significant contribution from British and Irish Native mares. Biol Lett 7:316-320

2. Cunningham EP, Dooley JJ, Splan RK, Bradley DG (2001) Microsatellite diversity, pedigree relatedness and the contributions of founder lineages to Thoroughbred horses. Anim Genet 32:360-364

3. Hill EW, Bradley DG, Al-Barody M, Ertugrul O, Splan RK, Zakharov I, Cunningham EP (2002) History and integrity of Thoroughbred dam lines revealed in equine mtDNA variation. Anim Genet 33:287-294

4. Jones JH, Lindstedt SL (1993) Limits to maximal performance. Annu Rev Physiol 55:547-569

5. Steelman CA, Recknor JC, Nettleton D, Reecy JM (2006) Transcriptional profiling of myostatin-knockout mice implicates Wnt signaling in postnatal skeletal muscle growth and hypertrophy. FASEB J 20:580-582

6. Murphy KT, Koopman R, Naim T, Léger B, Trieu J, Ibebunjo C (2010) Lynch GS Antibody-directed myostatin inhibition in 21-mo-old mice reveals novel roles for myostatin signaling in skeletal muscle structure and function. FASEB J 24:4433-4442

7. Hill EW, Gu J, Eivers SS, Fonseca RG, McGivney BA, Govindarajan P, Orr N, Katz LM, MacHugh DE (2010) A sequence polymorphism in MSTN predicts sprinting ability and racing stamina in Thoroughbred horses. PLoS One 20:e8645

8. Tozaki T, Hill EW, Hirota K, Kakoi H, Gawahara H, Miyake T, Sugita S, Hasegawa T, Ishida N, Nakano Y, Kurosawa M (2011) A cohort study of racing performance in Japanese Thoroughbred racehorses using genome information on ECA18. Anim Genet 43:42-52 
9. Tozaki T, Sato F, Hill EW, Miyake T, Endo Y, Kakoi H, Gawahara H, Hirota K, Nakano Y, Nambo Y, Kurosawa M (2011) Sequence variants at the myostatin gene locus influence the body composition of Thoroughbred horses. J Vet Med Sci 73:1617-1624

10. McCroskery S, Thomas M, Maxwell L, Sharma M, Kambadur R (2003) Myostatin negatively regulates satellite cell activation and self-renewal. J Cell Biol 162:1135-1147

11. Bower MA, McGivney BA, Campana MG, Gu J, Andersson LS, Barrett E, Davis CR, Mikko S, Stock F, Voronkova V, Bradley DG, Fahey AG, Lindgren G, MacHugh DE, Sulimova G, Hill EW (2012) The genetic origin and history of speed in the Thoroughbred racehorse. Nat Commun 3:643

12. Yamano S, Eto D, Kasashima Y, Hiraga A, Sugiura T, Miyata H (2005) Evaluation of developmental changes in the coexpression of myosin heavy chains and metabolic properties of equine skeletal muscle fibers. Am J Vet Res 66:401-405

13. Smith RK, Birch H, Patterson-Kane J, Firth EC, Williams L, Cherdchutham W, van Weeren WR, Goodship AE (1999) Should equine athletes commence training during skeletal development? Changes in tendon matrix associated with development, ageing, function and exercise. Equine Vet J Suppl 30:201-209

14. Kasashima Y, Smith RK, Birch HL, Takahashi T, Kusano K, Goodship AE (2002) Exercise-induced tendon hypertrophy: cross-sectional area changes during growth are influenced by exercise. Equine Vet J Suppl 34:264-268

15. Kawai M, Aida H, Hiraga A, Miyata H (2013) Muscle satellite cells are activated after exercise to exhaustion in Thoroughbred horses. Equine Vet J 45:512-517

16. Grobet L, Martin LJ, Poncelet D, Pirottin D, Brouwers B, Riquet J, Schoeberlein A, Dunner S, Ménissier F, Massabanda J, Fries R, Hanset R, Georges M (1997) A deletion in the bovine myostatin gene causes the double-muscled phenotype in cattle. Nat Genet 17:71-74

17. McPherron AC, Lee SJ (1997) Double muscling in cattle due to mutations in the myostatin gene. Proc Natl Acad Sci USA 94:12457-12461

18. Mosher DS, Quignon P, Bustamante CD, Sutter NB, Mellersh CS, Parker HG, Ostrander EA (2007) A mutation in the Myostatin gene increases muscle mass and enhances racing performance in heterozygote dogs. PLoS Genet 3:e79

19. McPherron AC, Lawler AM, Lee SJ (1997) Regulation of skeletal muscle mass in mice by a new TGF-beta superfamily member. Nature 387:83-90

20. Clop A, Marcq F, Takeda H, Pirottin D, Tordoir X, Bibé B, Bouix J, Caiment F, Elsen JM, Eychenne F, Larzul C, Laville E, Meish F, Milenkovic D, Tobin J, Charlier C, Georges M (2006) A mutation creating a potential illegitimate microRNA target site in the myostatin gene affects muscularity in sheep. Nat Genet 38:813-818

21. Schuelke M, Wagner KR, Stolz LE, Hübner C, Riebel T, Kömen W, Braun T, Tobin JF, Lee SJ (2004) Myostatin mutation associated with gross muscle hypertrophy in a child. N Engl J Med 350:2682-2688

22. Tozaki T, Miyake T, Kakoi H, Gawahara H, Sugita S, Hasegawa T, Ishida N, Hirota K, Nakano Y (2010) A genome-wide association study for racing performances in Thoroughbreds clarifies a candidate region near the MSTN gene. Anim Genet 41(S2):28-35

23. Petersen JL, Mickelson JR, Rendahl AK, Valberg SJ, Andersson LS, Axelsson J, Bailey E, Bannasch D, Binns MM, Borges AS,
Brama P, da Câmara Machado A, Capomaccio S, Cappelli K, Cothran EG, Distl O, Fox-Clipsham L, Graves KT, Guérin G, Haase B, Hasegawa T, Hemmann K, Hill EW, Leeb T, Lindgren G, Lohi H, Lopes MS, McGivney BA, Mikko S, Orr N, Penedo MC, Piercy RJ, Raekallio M, Rieder S, Røed KH, Swinburne J, Tozaki T, Vaudin M, Wade CM, McCue ME (2013) Genomewide analysis reveals selection for important traits in domestic horse breeds. PLoS Genet 9:e1003211

24. Rivero JL, Hill EW (2016) Skeletal muscle adaptations and muscle genomics of performance horses. Vet J 209:5-13

25. Roth SM, Martel GF, Ferrell RE, Metter EJ, Hurley BF, Rogers M (2003) Myostatin gene expression is reduced in humans with heavy-resistance strength training. Exp Biol Med 228:706-709

26. Hulmi JJ, Ahtiainen JP, Kaasalainen T, Pollanen E, Hakkinen K, Alen M, Selanne H, Kovanen V, Mero AA (2007) Post exercise myostatin and activin IIb mRNA levels: effects of strength training. Med Sci Sports Exerc 239:289-297

27. Hill EW, Fonseca RG, McGivney BA, Gu J, MacHugh DE, Katz LM (2012) MSTN genotype (g.66493737C/T) association with speed indices in Thoroughbred racehorses. J Appl Physiol 112:86-90

28. Seo S, Takayama K, Uno K, Ohi K, Hashimoto R, Nishizawa D, Ikeda K, Ozaki N, Nabeshima T, Miyamoto Y, Nitta A (2013) Functional analysis of deep intronic SNP rs13438494 in intron 24 of PCLO gene. PLoS One 8(10):e76960

29. Millar DS, Horan M, Chuzhanova NA, Cooper DN (2010) Characterisation of a functional intronic polymorphism in the human growth hormone (GH1) gene. Hum Genom 4(5):289-301

30. Tatsumi R, Hattori A, Ikeuchi Y, Anderson JE, Allen RE (2002) Release of hepatocyte growth factor from mechanically stretched skeletal muscle satellite cells and role of $\mathrm{pH}$ and nitric oxide. Mol Biol Cell 13:2909-2918

31. Reimann J, Brimah K, Schröder R, Wernig A, Beauchamp JR, Partridge TA (2004) Pax7 distribution in human skeletal muscle biopsies and myogenic tissue cultures. Cell Tissue Res 315:233-242

32. Yablonka-Reuveni Z, Rudnicki MA, Rivera AJ, Primig M, Anderson JE, Natanson P (1999) The transition from proliferation to differentiation is delayed in satellite cells from mice lacking MyoD. Dev Biol 210:440-455

33. Schultz E, Chamberlain C, McCormick KM, Mozdziak PE (2006) Satellite cells express distinct patterns of myogenic proteins in immature skeletal muscle. Dev Dyn 235:3230-3239

34. Wright WE, Sassoon DA, Lin VK (1989) Myogenin, a factor regulating myogenesis, has a domain homologous to MyoD. Cell $56: 607-617$

35. Rhoads RP, Flann KL, Cardinal TR, Rathbone CR, Liu X, Allen RE (2013) Satellite cells isolated from aged or dystrophic muscle exhibit a reduced capacity to promote angiogenesis in vitro. Biochem Biophys Res Commun 440:399-404

36. Christov C, Chrétien F, Abou-Khalil R, Bassez G, Vallet G, Authier FJ, Bassaglia Y, Shinin V, Tajbakhsh S, Chazaud B, Gherardi RK (2007) Muscle satellite cells and endothelial cells: close neighbors and privileged partners. Mol Biol Cell 18:1397-1409

37. Ploquin C, Chabi B, Fouret G, Vernus B, Feillet-Coudray C, Coudray C, Bonnieu A, Ramonatxo C (2012) Lack of myostatin alters intermyofibrillar mitochondria activity, unbalances redox status, and impairs tolerance to chronic repetitive contractions in muscle. Am J Physiol 302:E1000-E1008 